\title{
Alcohol-Drug Addiction Research, Treatment and Training Centers (AMATEM) in the Treatment of Substance Use Disorder
}

\author{
Madde Kullanım Bozukluğu Tedavisinde Alkol-Madde Bağımlılığı \\ Araştırma, Tedavi ve Eğitim Merkezleri (AMATEM)
}

\author{
DDehmet Hamdi Örüm \\ Kahta Devlet Hastanesi, Psikiyatri Kliniği, Adıyaman, Türkiye \\ Copyright (C) 2020 by authors and Medical Records Publishing Inc.
}

\section{Dear Editor,}

Addiction is a brain disease that is manifested by compulsive substance use despite negative consequences $(1,2)$. People with addiction have an intense focus on using a certain substance, such as alcohol or drugs, to the point that it takes over their life $(3,4)$. They keep using alcohol or a drug even when they know it will cause problems. Yet a number of effective treatments are available and people can recover from addiction and lead normal, productive lives (5). Untreated alcohol and drug addiction continues to be a major health issue worldwide $(6,7)$. Addiction treatment is carried out in Alcohol-Drug Addiction Research, Treatment and Training Centers (AMATEM) in our country (8-10). Our aim in this paper is to provide general information about AMATEM, so that all clinicians will benefit.

AMATEM clinics have been serving since the 1980s in Turkey (8). These clinics serve for the termination of substance addiction and re-functioning of individuals $(10,11)$. There is no a standard treatment. Medical, psychological and social interventions are individual. The priority is to focus on patients' denial mechanisms (9). Patients are informed about possible negative consequences of addiction. In the treatment process, a combination of medication and individual or group therapy is most effective. Medications are used to control drug cravings and relieve severe symptoms of withdrawal. Therapy can help addicted individuals understand their behavior and motivations, develop higher self-esteem, cope with stress and address other mental health problems. Treatment may also include hospitalization, therapeutic communities, outpatient programs. Motivational talks are held. Withdrawal symptoms may be indication for inpatient treatment. However, inpatient treatment is voluntary $(8,12)$. Post-discharge follow-up continues at AMATEM outpatient clinics $(10,13)$.

One of the leading institutions in the fight against addiction in our Turkey is Yeşilay. According to the data of Yeşilay, the number of AMATEM inpatient unit in the city centers is 31 ; the number of AMATEM outpatient unit is 27 ; the number of child substance addiction treatment center (ÇEMATEM) inpatient unit is 7; the number of ÇEMATEM outpatient unit is 7. Apart from these city centers, AMATEM units can be provided in some counties (e.g., Adiyaman Kahta State Hospital) (14). These centers are located in many different regions and cities of the country. It is appreciated that the social, economic and cultural variables of each region are different. These differences are reflected in substance use characteristics. Considering that AMATEM data shows regional changes, interventions based on regional differences will be beneficial. Also AMATEM data varies over time (8). For this reason, AMATEM data of the regions should be revealed regularly and compared with previous years. Various AMATEM findings are reached through the literature $(9,10)$. Based on these data, it is possible to make various comparisons. The mean age, gender, psychiatric diagnoses vary from region to region. The substance use characteristics of individuals determined by external factors. Over the years, the difficulties or conveniences experienced in achieving the substance, the state policy, the changes in the drug production areas, the 
market shares of the substances, the powers dominating the substance market are some conditions affecting the substance use orientation (8-10).

As a result, epidemiological studies are of great importance in the fight against substance abuse, which continues to be a serious public health problem. Sharing the findings of all AMATEM clinics regularly will increase the success of social interventions.

Financial disclosures: All authors report no financial interests or potential conflicts of interest.

Conflict of Interest: The authors declare that they have no competing interest.

\section{REFERENCES}

1. Örüm $M H$, Kara $M Z$, Kuştepe A, Kalenderoğlu A. Bilişsel hatalar ve dikkat-eksikliği hiperaktivite bozukluğu belirtilerinin madde kullanım özellikleri ile ilişkisi. Bağımlılık Dergisi 2019;20(2):47-60.

2. Kalenderoglu A, Orum MH, Karadag AS, Kustepe A, Celik M, Egilmez OB, Eken-Gedik D. Increases in retinal nerve fiber layer thickness may represent the neuroprotective effect of cannabis: an optical coherence tomography study. J Addict Dis. Doi: 10.1080/10550887.2020.1754109.

3. Orum $\mathrm{MH}$, Kara MZ. Platelet to lymphocyte ratio (PLR) in alcohol use disorder. J Immunoassay Immunochem 2020;41(2):184-94

4. Kustepe A, Kalenderoglu A, Celik M, Kaya-Bozkurt E, Orum $\mathrm{MH}$, Uguz S. Evaluation of impulsivity and complex attention functions of subjects with substance use: Sample from Adiyaman province. Med Sci 2019;8(1):67-71.

5. Orum MH, Kustepe A, Kara MZ, Dumlupinar E, Egilmez OB, Ozen ME, Kalenderoglu A. Addiction profiles of patients with substance dependency living in Adiyaman province. Med Sci 2018;7(2):369-72.
6. Egilmez $\mathrm{OB}$, Örüm $\mathrm{MH}$, Dumlupınar E. Comparative analysis of the probation implementations in Adıyaman province: The data of 2017 and 2018. Kırıkkale Üniversitesi Tıp Fakültesi Dergisi 2020;22(1):30-8.

7. Eğilmez OB, Örüm MH. 2015-2018 yılları arasında bir erişkin psikiyatri servisinde yatan ergen hastaların TSH, FT3, FT4, vitamin B12, folat ve ferritin düzeylerinin cinsiyet ve tanılarına göre incelenmesi. J Neuro Behav Sci 2020;7(1):27-31.

8. Eğilmez $\mathrm{OB}$, Örüm $\mathrm{MH}, \mathrm{Kara} \mathrm{MZ}$. Retrospective analysis of AMATEM patients treated in psychiatry inpatient unit of Adiyaman Training and Research Hospital: Data for 2018. Bezmialem Science 2020;8(2):106-12.

9. Orum MH, Egilmez OB, Kara MZ. Comparison of AMATEM data of Adiyaman province for 2017-2018 and determination of alcohol-drug orientation. Psychiatry and Behavioral Sciences 2019;9(4):198-200.

10. Egilmez OB, Örüm MH, Kara MZ. Adıyaman ili AMATEM verilerinin geriye dönük olarak incelenmesi: 2018 yılı verileri. Bağımlılık Dergisi 2019;20(2):88-96.

11. Ozen ME, Orum MH, Kalenderoglu A, Atmaca M. Attentiondeficit/hyperactivity disorder in patients attending remedial treatment due to substance use disorder in Adiyaman University Training and Research Hospital. Psychiatry Behav Sci 2018;8(2):57-62.

12. Egilmez OB, Örüm MH, Dumlupınar E, Egeli A. Denetimli serbestlik uygulaması kapsamında yapılan başvuruların geriye dönük olarak değerlendirilmesi: 2018 yılı verileri. Bağımlılık Dergisi 2019;20(2):80-7.

13. Orum MH, Kara MZ, Egilmez OB, Ozen ME, Kalenderoglu A. Evaluation of probation implementations of drug users in Adiyaman university training and research hospital: A oneyear retrospective study. Med Sci 2018;7(4):754-8.

14. http://www.yedam.org.tr/amatem-cematem. Erişim Tarihi: 27.04.2020. 